\title{
UNIVERSITY of \\ STIRLING
}

Management School

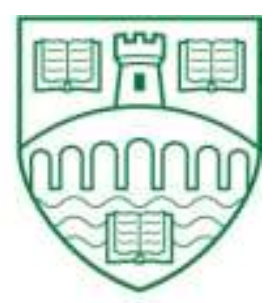

\section{Who gained from the introduction of free universal secondary education in England and Wales?}

Robert A. Hart

Mirko Moro

J. Elizabeth Roberts

December 2015

This is a pre-copyedited, author-produced PDF of an article accepted for publication in Oxford Economic Papers following peer review. The version of record Robert A. Hart, Mirko Moro, J. Elizabeth Roberts; Who gained from the introduction of free universal secondary education in England and Wales?, Oxford Economic Papers, Volume 69, Issue 3, 1 July 2017, Pages 707-733 is available online at: https://doi.org/10.1093/oep/gpw039 


\title{
Who gained from the introduction of free universal secondary education in England and Wales?
}

\author{
Robert A. Hart, Mirko Moro, J. Elizabeth Roberts \\ Division of Economics \\ University of Stirling
}

December, 2015

\begin{abstract}
:
This paper investigates the introduction of free universal secondary education in England and Wales in 1944. It focuses on its effects in relation to a prime long-term goal of pre-war Boards of Education. This was to open secondary school education to children of all social backgrounds on equal terms. Adopting a difference-in-difference estimation approach, we do not find any evidence that boys and girls from less well-off home backgrounds displayed improved chances of attending selective secondary schools. Nor, for the most part, did they show increased probabilities of gaining formal school qualifications. One possible exception in this latter respect relates to boys with unskilled fathers.
\end{abstract}

JEL: I21, I24, I28

Keywords: 1944 Education Act, free secondary education, family background, school qualifications.

Acknowledgements: We are grateful to John Field, Gary McCulloch, Gill Sutherland, Anna Vignoles, and two anonymous referees for their helpful advice and comments. 
A core element of the work of Professor A. H. Halsey (1923-2014) concerns relationships between family origins and educational opportunities (Halsey et al., 1980). We focus on two specific questions visited in this work (Halsey and Gardner, 1953) which relate to the introduction of free universal secondary education under the 1944 Education Act in England and Wales. Did the Act improve the relative chances of boys and girls from less advantaged family backgrounds in gaining grammar school entry as well as nationally recognised school qualifications?

\section{Introduction}

The 1944 Education Act in England and Wales is considered to be one of the great social reforms of the Twentieth Century. It is commonly referred to as the Butler Act, after the Conservative politician R.A. 'Rab' Butler, the then President of the Board of Education. The Act has featured prominently in the socio-economic literature. Much of this work has concentrated on examining the consequences of one aspect of the reforms, the extension in 1947 of the minimum school leaving age from 14 to 15. Examples include the effects on labour market earnings (Harmon and Walker, 1995; Oreopolous, 2006; Devereux and Hart, 2010), health outcomes (Clark and Royer, 2013; Powdthavee , 2010), and old age cognitive abilities (Banks and Mazzonna, 2012). First and foremost, however, the Act established free universal secondary education. This was principally delivered in the form of a state-maintained tripartite system consisting of selective grammar and technical schools and nonselective modern schools.

We concentrate in this paper on a question relating to a critical underlying objective behind the new system. Did the reforms succeed in improving the chances of children from poorer backgrounds in obtaining selective secondary school places as well as nationally recognised secondary school qualifications? In a modern context, this is an important consideration. Some European countries, including the UK, and some cities in the USA, have systems in place that allow schools to select their pupils on the basis of academic ability. Although the bulk of evidence does not support the hypothesis that selective schools have large effects on test scores (see e.g., Clark 2010, Pop-Eleches and Urquiola, 2013), selective schools may improve longer-run and labour market outcomes (see Clark and Del Bono, 2014). 
Floud (1954) reports that, starting before WWI, Boards of Education in England and Wales had the long-term objective of opening secondary school education to children of all social backgrounds on equal terms. A move to improve the chances of poorer children gaining entry to a selective secondary school - often referred to as a secondary (grammar) school - started as early as 1907 with a proportion of places offered free on the basis of performance in a competitive $11+$ exam. ${ }^{1}$ We know that, in respect of achieving places in selective grammar schools, this was not achieved in the subsequent decades up to WWII. Significant proportions of grammar school places were noncompetitively allocated to children whose parents could afford to pay fees. Improvements were achieved, however. Between 1907 and 1938, the proportion of free secondary school places rose from 24 percent to 47 percent. $^{2}$ The introduction of universal free state secondary education under the 1944 Act may have been expected to provide equal opportunities for able children across the social spectrum in respect of receiving selective grammar school education and gaining formal school qualifications.

The growing availability of free places pre-1944 went hand in hand with large increases in the proportions of boys and girls coming from skilled/semi-skilled/unskilled family backgrounds and achieving selective secondary school places. But total selective secondary school places were also expanding and resulted in even larger proportional increases in attendances among boys and girls from higher-level occupational households. Floud (1954) reports that, at the end of the 1930s, boys coming from professional/ managerial/ higher-grade non-manual families were more than 4 times likely to gain a selective secondary school place compared to boys from skilled manual families. Equivalently, girls were 3 times more likely. Compared with boys and girls from semi-

\footnotetext{
${ }^{1}$ The term ' $11+$ exam' was used in the periods before and after the Butler Act to denote a series of tests at the end of junior school - mainly taken by children at age 11 but also for some at age 12 - to determine placement in secondary school education.

${ }^{2}$ Eligibility to take the $11+$ exam was not means-tested; competition for free places was open to children from all family backgrounds.
} 
skilled/unskilled family backgrounds, boys and girls in the three top family occupational groups had, respectively, 5 and 6-7 times more chance of attending a selective secondary school.

In 1933, $49 \%$ of selective secondary school places were allocated non-competitively to fee payers. Even as late as 1938, 31\% of places were allocated in this way (see Floud, Table 2, Appendix 2). Not only were fees abolished under the 1944 Act but all children entering state secondary schools had to take a competitive 11+ examination. A priori, this introduction of a more level playing field might have been expected to improve the relative probabilities of able poorer children achieving selective places. Moreover, since attendance at a selective school was, for the great majority of pupils, the only way to obtain formal nationally-recognised secondary school qualifications between the ages of 11 and 18 then it might be likewise expected that there were relatively improved qualification successes among poorer children.

Unfortunately, an expectation of larger representations of poorer children in selective schools after the Butler reforms was open to serious question. There are at least two important reasons for this. First, Halsey and Gardner (1953) report that, " the poorer working class parents refused the offer of free places for their children with astonishing frequency'. Based on their own and other cited work, reasons given included foregone earnings, inadequate maintenance grants, parents not wanting to see their children in the sort of occupations associated with a grammar school education. By contrast, parents in professional or supervisory occupations were more likely to express preferences for (a) grammar school education, (b) a longer stay at secondary school, (c) the need for post-school further education (Martin, 1954). Second, a view emerged that the nature of IQ testing under the 11+ exam was itself not independent of family circumstances. Some sociologists pointed to 'the influence of intelligence tests in discriminating against working-class children at eleven plus' (Rubinstein and Simon, 1969). For example, the 11+ exam included tests of general reasoning in which the use of 
language, correct grammar and sentence logic played important roles. Children with professional and relatively highly educated parents may have had home-based advantages in these respects. ${ }^{3}$

We compare the probabilities, in the eras before and after the 1944 Education Act, of attending a grammar school and of gaining formal secondary school qualifications in respect of cohorts of children classified by father's occupational satus (managerial/professional, skilled, and unskilled) ${ }^{4}$ and parental qualification (parents with some qualifications vs parents with no qualifications). We also investigate outcomes when gender is interacted with father's occupation or with parental qualifications. We do so by taking advantage of a rich set of information on family background included in the British Household Panel Study. The work relates to the existing literature on the link between family background and children's outcomes and more generally to intergenerational mobility. There is strong evidence that parents' occupations or income and whether or not they hold qualifications have strong bearings on their children's secondary education placements and achievements in both developed and developing countries (see e.g., Ermisch and Francesconi, 2001; Brunello and Checchi, 2003; Dustmann, 2004; Woessmann, 2004 and 2005; Lauer, 2012).

The relationship between family background and children's outcomes is typically complicated because of omitted variables. For instance, parental ability and its inheritability are not randomly assigned. Few studies have dealt with this form of endogeneity within the extant literature. ${ }^{5}$

\footnotetext{
${ }^{3}$ In our subsequent empirical work we control for these sorts of parental influences in two ways. First, we control for the father's and the mother's educational backgrounds. Second, we include a control depicting whether a given household possessed (a) a lot or (b) quite a few or (c) not many books.

${ }^{4}$ There is a long history of researchers finding evidence of a strong positive association between the incidence of attending a grammar school and parents' occupational status. See, for example, Lindsay (1926) who provides occupational breakdowns for the parents of boys and of girls who attended English secondary schools in 1913 and 1921.

${ }^{5}$ For example, Plug and Vijverberg (2001) use adoption as a natural experiment and found that family income does matter for adopted children. Exogenous variation in parental education brought about by 
We use difference-in-difference (DD) technique to control for omitted variables as is typically done in program evaluation studies (e.g., Imbens and Wooldridge, 2009). We compare the performances of pupils from less well-off family backgrounds with those from relatively wealthy backgrounds before and after the Butler Act. In this setting, children from poorer families can be regarded as treated by the reform to provide free universal secondary education, while children with richer backgrounds provide the control group. The latter are identified as children with fathers in professional or managerial occupations. We show that outcomes of children from poorer and richer backgrounds follow a statistically similar trend before the reform, which provides validity of our methodology (see, e.g., Angrist and Pischke, 2009). The same strategy is followed when comparing children with parents who have or do not have qualifications.

Our birth cohorts cover the period from 1915 to 1953. The end-year is chosen to coincide with children aged 11 in 1964, a year that marked official government policy and action to move away from the tripartite system. We divide the study period into three sub-periods. First, the period covering children who were born before 1933 and who entered secondary school before the 1944 Act took effect. Second, that covering children born between 1933 and 1936 who started secondary school in the early tripartite years and whose education may have been adversely affected during the transition phase of operationalizing the new system. This involved disruptions and delays due to a build-up in the provision of appropriately trained teachers, school refurbishments and new building construction, and the provision of adequate administrative structures (see Dent, 1954). Third, that covering children born in 1937 and later years who started secondary school when the new framework was more or less in full operation, including the delayed implementation of the raised minimum school leaving age from 14 to 15.

compulsory schooling has been found to have positive impact on children's outcomes (see, e.g., Chevalier, Harmon, O'Sullivan, and Walker, 2010). 
Our results can be summarised as follows. We do not find evidence that children from poorer home backgrounds displayed improved relative chances of attending selective school or gaining formal school qualifications as a result of the reform. However, when we distinguish between genders, we find some evidence that males with unskilled fathers were more likely to gain formal school qualifications following the introduction of the Butler Act.

\section{Secondary education pre- and post- Butler reforms}

\section{(i) Pre-Butler}

The Education Act of 1918, implemented in 1921, raised the official school minimum leaving age from 12 to 14 and this remained in force until 1947. Over these years, most pupils attended elementary schools for their complete school education although the schools were often separated into primary and secondary sections. There was a growing desire, however, to move away from a catch-all elementary school model. ${ }^{6}$ Leading in this direction was the goal of catering for children who, for the most part, were likely to benefit from school study beyond the age of 14. Local Education Authorities (LEAs) increasingly provided free standing grant-aided secondary schools. ${ }^{7}$

A 'secondary school' was officially defined as 'offering to each of its scholars up to and beyond the age of sixteen a general education, physical, mental and moral, given through a complete graded course of instruction of wider scope and more advanced degree than that given in elementary schools' (Norwood Report, 1943). By 1932, the percentage of pupils attending grant aided secondary

\footnotetext{
${ }^{6}$ The Hadow Report (1926) recommended that at the age of about 11 (referred to as 11+), children should move from primary school to various types of 'post-primary' education in which most would subsequently leave at ages 14 or 15 , many at 16 , and some at 18 or 19 . Such objectives were largely realised in the 1944 Education Act.

${ }^{7}$ Grant-aided secondary schools featured most prominently although there were secondary schools that received no grant. In terms of grant support, there were schools that received a grant from (a) the Board of Education, (b) both the Board and the LEA. Some schools were wholly maintained by the LEA.
} 
schools who had previously attended elementary schools reached 73\% (Spens Report, 1938). Pupil transfers from elementary to secondary school took place at the ages of 11 and $12 .{ }^{8}$ Apart from elementary and secondary schools, other schools for children aged 11 and over included junior technical schools, junior commercial and trade schools, and senior schools. As in the post-Butler years, public and private schools also featured in the secondary educational portfolio.

Table 1 provides a snap-shot of secondary school numbers in March 1937. Three features stand out. First, up to the minimum school leaving age of 14, elementary school registrations dominated the total pupil numbers. Second, the large majority of elementary pupils left school at age 14. Third, pupils attending grant-aided secondary schools climbed in numbers at ages $11 / 12$, showed a 5.4\% decline in numbers between the ages of 14 and 16, and a larger 37\% drop beyond that age. The maintenance of numbers up to age 16 and the large retention of numbers up to age 17/18 were due in large part to the timing of two external public examinations, the School Certificate and the Higher Certificate.

The provision of free secondary education was by no means uncommon throughout the first half of the century. Children competed for the allocated free places through a competitive 11+ exam taken at the end of primary school. In 1907, 24\% of secondary school pupils were exempt from fees, by the early 1920s this had risen to about one-third, and by 1932 to $48 \%$. Thereafter, between 1933 and 1938 under the so-called special place regulations ${ }^{9}$, a slight drop in the percentage in no fees secondary school places was offset by increases in the percentage of part fees places. In 1938, non-

\footnotetext{
${ }^{8}$ In England transfers were typically aged 11, in Wales they were at age 12.
}

${ }^{9}$ There were large scale educational cutbacks in the early 1930s against the backdrop of the Great Depression. There was a halt to new school building as well as reductions in staff numbers and salaries. School fees were increased and the household income levels that triggered eligibility for maintenance support were reduced. Competitively allocated places were now labelled special rather than free places. The key difference was that fee re-assessments meant that a proportion of competitive places were now subject to either full or partial fees. The total number of special places in 1933 differed little in number from the free places offered in 1932. 
fee special places accounted for $52.6 \%$ of total secondary school entry, while $9.9 \%$ were part-fee special places, and $6.8 \%$ full-fee special places. The remaining $30.7 \%$ of secondary school pupils gained places on a full fee non-competitive basis (Floud, 1954, Appendix 2).

In order to obtain a School Certificate, usually at age 16, examination candidates were required to display a reasonable level of competence in English subjects, Science and Maths, and Languages (see Norwood Report, 1943). ${ }^{10}$ The Higher Certificate was taken one or (increasingly) two years later and comprised a specialised mix of courses at a more advanced level. Figure 1 shows the numbers of pupils by gender entered for the Certificate and the Higher Certificate between 1924/5 and 1936/7. In England, between 5\% and 8\% of secondary school leavers aged 16 and over proceeded directly to university between 1932 and 1937. In Wales the range was 8\% to 13\% (Spens Report, Chapter II, Table 14).

(ii) Post-Butler

The state-funded or so-called 'maintained' tripartite schooling system established by the 1944 Education Act delivered free secondary education via selective grammar schools ${ }^{11}$, selective technical schools $^{12}$ and nonselective modern schools ${ }^{13}$. Between 1947 and 1964, this three-tier system was dominant, offering the only choice of secondary education to the great majority of children in their

${ }^{10}$ Typically, a Certificate candidate studied for 7 subjects with examinations lasting for the equivalent of 6 days. If a candidate failed, the examination diet could be repeated six months or 12 months later.

${ }^{11}$ Grammar school education emphasised an academic curriculum, covering literature, mathematics, science, old and new languages.

${ }^{12}$ Technical school education placed strong emphasis on applied mechanical sciences and engineering.

${ }^{13}$ The modern curriculum concentrated on practical and basic subjects, including arithmetic, wood work and metal work, domestic work. 
LEAs. ${ }^{14}$ In 1947, 38\% of pupils in the tripartite system attended maintained grammar schools. This share declined to $26 \%$ by 1964 , although most of this was concentrated in the years 1947 to 1950 (Bolton, 2013). The great majority of grammar schools already existed due to the pre-Butler expansion of secondary (grammar) schools. The build-up of the rest of the publicly funded secondary sector, effectively the secondary modern schools, took longer. Secondary modern school provision necessitated the conversion of pre-existing elementary schools alongside a significant increase in new school building. The year 1964 marked the end of official government backing of the system. ${ }^{15}$ Over the period 1947 to 1964 our BHPS sample indicates that that $64 \%$ of students in state-run secondary education attended modern schools, 31\% attended grammar school, and 5\% attended technical schools..$^{16}$

Gaining a selective secondary school place on the basis of the 11+ exam was not conditional on a predetermined pass/fail mark. At an important margin, it depended on the relative availability of places through time and across geographical education districts. There was significant district variation in the LEA provision of grammar and technical school places.

Success or failure in the 11+ exam had potentially serious long-term implications for pupils' future educational and labour market attainments. Once placed, very few transfers took place

${ }^{14}$ Between 1947 and 1964 direct grant, or fee-paying, grammar schools accounted for $1.3 \%$ of all students and had to make at least $25 \%$ of their places available to state primary school children whose education was paid for by the state. There were 13 comprehensive schools in 1953 rising to 195 by 1964 (Mitchell, 1988, p. 807). Public school and private school students accounted for the remaining sizeable share of pupils from 1947 to 1964 , at 5.2\%.

${ }^{15}$ In 1965, the new Labour government requested LEAs to start planning for and switching towards a radically different comprehensive education system (see Sumner, 2010). Despite sharp declines in pupil shares, grammar school provision remained important in England and Wales up to the mid1970s. See Clark (2010) for a detailed analysis of the impact of attending selective grammar schools in one English district during the late 1960s/early 1970s.

${ }^{16}$ These relative percentages are in line with data provided by Mitchell (1988) covering all children attending secondary schools in the maintained sectors in England and Wales for the years 1947 to 1964; 66\% attended modern schools, 29\% grammar schools, and $4 \%$ technical schools. 
between nonselective modern schools and selective grammar/technical schools. While post-school further education opportunities were not ruled out, "schooling at least was settled at the age of 11 " (Halsey, Heath, and Ridge, 1980, p.105). As in the pre- Butler era, two national exams were available for suitable pupils aged 16 and 17/18. These were, respectively the General Certificate of Education at ordinary level (O-level) and advanced level (A-level). Candidates taking the school O-level and Alevel exams as well as first and higher university degrees overwhelmingly represented those educated selective schools. ${ }^{17}$ Of all secondary school pupils between 1947 and 1964 in our BHPS sample, 19\% achieved O-level qualifications, $8 \%$ A-level, $7 \%$ a first degree, and 2\% a higher degree.

In summary, the secondary school systems in the pre- and post- Butler eras were reasonably similar and by the time of the switch of regimes they had converged quite considerably. Elementary schools and secondary modern schools offered no formal qualifications. Grammar school curriculums were similar and offered nationally recognised exams at the ages of 16 and 17/18. The Butler Act introduced free universal secondary education under the tripartite system. By the end of the preButler years, nearly $50 \%$ of children attending grant-aided grammar schools paid no fees and a further $10 \%$ paid part-fees. Finally, entry into tripartite grammar schools was based solely on competitive entry, while competitive entry applied to $70 \%$ of secondary school places immediately before Butler.

\section{Pre- and post- Butler secondary education and relative outcomes}

The Hadow Report (1926), the Spens Report (1938) and the Norwood Report (1943) provided the essential building blocks for the structuring of secondary schools, allocation of students at age 11, curriculum, and examination systems under Butler. In essence, the pre-Butler elementary schools, grant-aided secondary schools and junior technical schools were the antecedents, respectively, of

${ }^{17}$ There were relatively few technical schools. From 1947 to 1964 there was an average of only 275 schools. This sector was generally under-resourced and experienced a scarcity of suitably qualified teachers. In what follows we group grammar and technical pupils together under the heading grammar school. 
modern schools, grammar schools and technical schools post-Butler. While the two secondary education eras shared several core features, there were also significant differences. The question arises as to whether the differences served significantly to alter the relative educational opportunities among the main family socio-economic groupings.

In the first place, the 1944 Education Act extended the provision of free education to all those who entered the tripartite system. Immediately pre-Butler, $50 \%$ of secondary school places for those remaining at school beyond the minimum leaving age of 14 were subject to full or partial fees. A general goal was to provide children from poorer home backgrounds with an equal opportunity to their fee-paying counterparts of attending a selective secondary school. However, the exam-based allocation of free places in the pre-Butler years fell well short of establishing such equity. Evidence is provided by a 1949 British survey of life histories covering the education, occupation and other social characteristics of a random sample of 10,000 adult males and females (Glass and Hall, 1954). Based on an analysis of the survey data, Floud (1954) finds that "not only a child's chances of getting to a secondary school at all, but also his chances of doing so as a holder of a free or special place (author's italics) were startlingly higher the higher his place in the social hierarchy - more than 6 times higher if he came from categories [professional, managerial, higher-grade] than from categories [semi-skilled manual, unskilled manual]."

Second, there was a clear difference between pre- and post- Butler eras in the degrees to which entry into selective or nonselective schools was based on competitive selection via examinations. While competitive exam-based entry grew in importance before Butler, there were still $30 \%$ of places allocated by other means in $1938 .{ }^{18}$ In contrast, all grammar school places in the

\footnotetext{
${ }^{18}$ In fact The Spens Committee (1938) saw advantages in basing selection into grammar schools and secondary modern schools on a mix of examinations, interviews and other selection methods. A written examination, it was argued, would detect pupils who would clearly benefit from the academic orientation of grammar schools and those who clearly would not. However, it recognised a middle group of pupils for whom an examination might not adequately pick up grammar school potential (see Drake 1939).
} 
tripartite system were subject to competitive exam-based entry. In many locations, therefore, competition for places increased in the later period (Dent, 1954, pp.70/71). The removal of feepaying places may have been expected to impact relatively favourably on less-well-off children. ${ }^{19}$

Third, there may have been differences in the underlying objectives of the formal school exams between the two eras (Dent, 1954). Pre-Butler, the School Certificates were first and foremost designed to assess the value of a general course of secondary education. The post-Butler General School Certificates, in contrast, were more forward looking with the objective of assessing candidate's potential to gain from more advanced education and training. To the extent that this was the case, it is difficult to judge whether or not this had implications for relative performances across socio-economic groups. The similarities of the two systems almost certainly outweighed the differences. Both sets of examination diets were taken at more or less the same ages and both embraced an academic curriculum that emphasised English language and literature, mathematics and science, old and new languages.

Fourth, the extension of the minimum school leaving age from 14 to 15 in 1947 probably had minimal impact, ceteris paribus, on relative grammar school entry across social groups. The secondary school selection process took place in both eras at the ages of 11 or 12 . For those who remained from 5 to 14 in elementary school pre- Butler and those who attended secondary modern school from 11 to 15 post- Butler, there was virtually no chance of achieving nationally recognised school qualifications during the years of secondary education. Formal national school exams in both eras did not take place before the age of 16 . We argue later, however, that raising the school minimum leaving age may have served to improve the chances of working class selective school children of gaining formal school qualifications.

${ }^{19}$ A possible caveat should be mentioned. The IQ tests that featured in the $11+$ examination were viewed by some as not being independent of family circumstances. There were criticisms of the methods of measuring intelligence (see Heim, 1954) with sociologists pointing out that the tests discriminated against working class children (Rubinstein and Simon, 1969). 


\section{BHPS data}

We base our empirical work on individual-level data taken from the British Household Panel Survey (BHPS). Our choice of variables together with the age of our included respondents (i.e. born before 1954) restricts us to using approximately 6000 BHPS respondents. Figure 2 shows annual official birth registrations together with the comparable sample BHPS birth cohorts from 1906 to 1953. Survivor bias might be a concern for studies of this type. The year-to-year movements of the two series are closely associated from about 1915. In earlier years, the upward trend in the BHPS sample and the flat/downward trends in official registrations represent attrition effects in the BHPS due to deaths. Accordingly, we chose 1915 as our starting birth year.

The BHPS provides great detail on individual demographic characteristics (date and district of birth), type of school attended, qualifications, etc. The parental social class variables used in our analysis are available in 1991, the first wave of the BHPS and therefore cover most of our sample. This information becomes available again in a few waves from 1998 to 2008 and this allows us to capture additional respondents. The family history variables (e.g. number of books in the household, place of birth, number of siblings etc.) are only given in 2003. The complete list of variables used in our analysis is presented in Table A1 in the Appendix.

Table 2 shows the percentages of individuals attending secondary schools in our two sets of birth cohorts in the BHPS samples. Both pre- and post- Butler, grammar schools and elementary/modern secondary schools form the largest intakes and are roughly equivalent in importance. For those attending secondary schools in the pre- Butler period, the BHPS questionnaire asks if individuals attended grammar school or elementary school, or secondary/secondary modern 
school or technical school, or public/private school or comprehensive school, or 'other' type of school. $^{20}$

\section{Basic trends}

In this section we examine some simple trends in the data, based on 3-year moving averages by year of birth, in respect of differentiations by father's occupation. Occupations are divided into (a) professional occupations (management and professional), (b) skilled occupations (skilled manual and non-manual), and (c) unskilled occupations (semi-skilled and unskilled). We indicate the transition period that affected children born in the years 1933 to 1936 . These children started secondary school during the phase between the introduction and full implementation of the tripartite system. Since we control for gender in the subsequent regressions, we show the trends for males and females separately.

As far as the probabilities of attending a grammar school are concerned, Figures 3 and 4 reveal reasonably consistent trends by gender and across fathers' occupational backgrounds. In particular, there appears to be no major convergence among the three occupational graphs in the postcompared with the pre- Butler eras.

Such uniformity is not so apparent in the case of boys who attended grammar school and gained school qualifications broken down by father's occupational status. Trends are shown in Figure 5. For boys born between the early 1930s and late- 1940s who had unskilled fathers, there was a sustained improvement in proportions achieving qualifications relative to the two other groups. This

${ }^{20}$ Since grant-aided secondary schools were referred to as grammar schools in this period, it is unclear how 'secondary/secondary modern school' should be interpreted. As mentioned above, those born before but near to 1936 could well have ended their school years in a secondary modern school after starting in an elementary school. Others might have meant by secondary school either a grammar school or the secondary-level section of an elementary school. Since most grammar school pupils left school at age 16 or above, we re-allocated individuals who reported secondary/secondary modern as follows. If they left school at 15 or younger, they were allocated to an elementary school. If they left school at 16 or older, they were classified as a grammar school pupil. In general, this is probably a quite accurate allocation. In fact, $90.5 \%$ of the total in this category indicated that they left school at 13 or 14 and these almost certainly would not have been grammar school pupils. Equally, those aged 16 and over were almost certainly not former elementary school pupils (see Table 1). 
improvement affected those who entered a grammar school during the war and in the Butler era. In terms of school qualification, they all could have benefited from the Butler reforms. Since free universal education was introduced in 1944 and since formal school examinations did not occur until the fifth year of grammar school education, some of those boys who entered grammar school before 1944 could have benefited from the free provision during their later years at school. From Figure 6, we find that girls from families with unskilled fathers did not display a comparable shift in achievement. There is some suggestion, however, that proportions of girls gaining qualifications who had skilled fathers did show systematic improvement relative to those with professional fathers.

These graphs, while useful in revealing simple patterns in the data, could partially be driven by omitted variables. The next section illustrates our estimation strategy that is designed to overcome such drawbacks.

\section{Estimation}

The availability of a rich set of data covering both pre- and post-Butler years enables us to employ a DD methodology in order to recover unbiased estimates of the effect of the reform on children's outcomes by family background. Other estimation strategies are likely to produce biased estimates. For example, a simple comparison of post-Butler outcomes of children with richer vs poorer backgrounds would yield upward biased estimates. Differences in outcomes preceding the Butler Act would be entirely attributed to the reform itself. This is a classic case of omitted variable bias. Unobservable differences in inherited ability and pre-existing measures in place to improve the chances of poor are two such variables. A more valid approach- and one that is commonly used in time-series analysis - would, for example, consist of studying how the outcomes of children with poor backgrounds evolve around the Butler Act, testing for the existence of breaks after the reform came into existence. However, this event study methodology does not account for time effects that have 
nothing to do with the Act. ${ }^{21}$ Our strategy circumvents these types of problems by identifying a group of children from relatively well-off backgrounds. We compare the outcomes of less well-off children with their wealthier counterparts before and after the Butler Act.

Children with fathers in managerial or professional occupations are the reference group. We identify two treatment groups, children with manual and non-manual skilled fathers, and those with manual semi-skilled or unskilled fathers. Routh (1980) provides helpful comparative estimates of the average pay of males in each of these three occupational groupings. These are shown in Table 7 for the years contained in our samples. They are expressed as percentages of the simple average for all men $(=100) .{ }^{22}$ For the reference group, higher professionals average between 220 and 191, lower professionals between 113 and 81, and managers between 183 and 153. For the skilled group, clerks average between 64 and 67, and skilled manual between 64 and 77 and foremen between 95 and 97. For the unskilled group, semi-skilled manual average between 44 and 58, and unskilled manual between 45 and 54 .

The identifying assumption is that the outcomes of the reference group provide a valid counterfactual for the outcomes of the two treatment groups. This is also known as the common trend assumption: in the absence of the Butler Act, the average outcome of children from poorer families would have changed in the same way as the average outcome of the children from richer families. One can show that outcomes were following a common trend before the Butler Act. Visual inspection of trends of 3-year moving averages presented in the previous section satisfactorily shows that these groups are indeed comparable. A more formal analysis of these pre-trends will be provided in the robustness section.

${ }^{21}$ These types of regressions provide the causal coefficients of interest under unconfoundedness (Cameron and Trivedi, 2005; Imbens, 2004) which is very hard to validate.

${ }^{22}$ So, the averages take no account of relative changes in employment weights. 
We know that parents with professional qualifications are most likely to express preferences for selective school and post-school education (Martin, 1954). Also, middle-class families were more likely to offer support to children's educational needs through such means as helping with early reading, residing in locations with relatively high supplies of grammar school places, financing outside tutoring designed to supplement classroom education (Vernon, 1957). Accordingly, to provide alternative estimates, we select children who had either one or two parents with qualifications as the reference group while children with parents without qualifications act as the treatment group.

In principle, given that most children started their secondary education at age 11, the first pupils to undertake all their secondary schooling years under the terms and conditions of the 1944 Act were born in 1933. Therefore, when comparing outcomes pre- and post- Butler it may appear sensible to search for differences at that birth year. There are two complications, however. First, the transition from old to new systems involved a great deal of disruption involving recruiting and training teachers, building new schools, and refurbishing existing schools. The problems forced a two-year postponement of the rise the minimum school leaving age. ${ }^{23}$ Second, there were children who were already in secondary schools in 1944 that could have benefited from the provision of free education. While Section 108 of the 1944 Act enabled the Education Minister to facilitate provision in any given LEA if there were undue delays, it is not clear when LEA's provided support under this reform. We attempt to accommodate both issues in the estimations that follow.

In what follows, we refer to selective schools in both eras as grammar schools. Our core regressions differentiate between birth cohorts of individuals born (a) before 1933 and who started secondary school before 1944, (b) between 1933 - 1936 who started secondary school during the

${ }^{23}$ Under Sections 35 and 108 of the 1944 Education Act, the school leaving age was to be raised to 15 as from $1^{\text {st }}$ April, 1945. Since it was estimated at the outset that an additional 200,000 school places and 13,000 teachers would be required, the government decided to postpone the introduction to $1^{\text {st }}$ April, 1947. See Cabinet Paper, Raising the School Leaving Age, National Archives CAB 129/1/117. 
post-1944 transition period, (c) during or after 1937 and started secondary school in 1948. In our subsequent robustness checks (see Figures 7 and 8) we experiment by extending the transition period forward by several years since its length cannot be precisely established.

The differences in the probabilities of attending a grammar school and gaining a formal school qualification by father's occupation, and parents' qualifications before and after the reform are investigated using a linear probability model. We illustrate our DD approach in respect of father's occupation. We also examine the interactions between gender and each of father's occupation and parents' qualifications (triple DD).

Let $G_{i}=1$ if individual $i$ went to a grammar school and $G_{i}=0$ otherwise. Then, setting fathers in professional, technical or managerial occupations as the comparison (reference) group, the DD model of the probability of attending grammar school by father's occupation is expressed

$$
\begin{aligned}
G_{i}=a_{0} & +a_{1}\left(\text { Skilled }_{i} * \text { Post }_{i}\right)+a_{2}\left(\text { Skilled }_{i}\right)+a_{3}\left(\text { Post }_{i}\right)+ \\
& +a_{4}\left(\text { Skilled }_{i} * \text { Transition }_{i}\right)+a_{5}\left(\text { Skilled }_{i}\right)+a_{6}\left(\text { Transition }_{i}\right)+ \\
& +a_{7}\left(\text { Unskilled }_{i} * \text { Post }_{i}\right)+a_{8}(\text { Unskilled })+a_{9}\left(\text { Post }_{i}\right)+ \\
& +a_{10}\left(\text { Unskilled }^{*} \text { Transition }_{i}\right)+a_{11}\left(\text { Unskilled }_{i}\right)+a_{12}\left(\text { Transition }_{i}\right)+ \\
& +a_{13}\left(\text { Birth }_{i}\right)+\text { OZ }_{i}+e_{i},
\end{aligned}
$$

where Skilled $_{i}$ is a dummy indicating whether respondent's father had a (manual or non-manual) skilled occupation, Unskilled $_{i}$ identifies fathers as being in a partly skilled or an unskilled occupation, Post $_{i}$ is a dummy taking the value 1 if the individual's birth year is 1937 or later, Transition $i$ is a dummy if the birth year is 1933 to 1936 . In other words, Skilled $d_{i}$ and Unskilled $_{i}$ represent our treatment groups. We exclude pupils born in 1936, as some might be affected by the transitional arrangements and some might not. Additionally, $B i r t h h_{i}$ denotes the individual's year of birth, and $Z_{i}$ is a set of controls. 
The controls included in $Z_{i}$ are (i) gender, (ii) availability of books at home during the first 10 years of childhood, (iii) age position among household siblings, (iv) district of birth, (v) area of birth (city, suburban, etc.), (vi) father's and mother date of birth, ${ }^{24}$ (vii) respondent's date of birth. (See Table A1 for more details.)

As for our second question, let $Q_{i}=1$ if individual $i$ went to grammar school and achieved a school qualification and $Q_{i}=0$ otherwise. The model, equivalent to (1), is expressed

$$
\begin{aligned}
Q_{i}=b_{0} & +b_{1}\left(\text { Skilled }_{i} * \text { Post }_{i}\right)+b_{2}\left(\text { Skilled }_{i}\right)+b_{3}\left(\text { Post }_{\mathrm{i}}\right)+ \\
& +b_{4}\left(\text { Skilled }_{i} * \text { Transition }_{i}\right)+b_{5}\left(\text { Skilled }_{i}\right)+b_{6}\left(\text { Transition }_{i}\right)+ \\
& +b_{7}\left(\text { Unskilled }_{i} * \text { Post }_{i}\right)+b_{8}(\text { Unskilled })+b_{9}\left(\text { Post }_{i}\right)+ \\
& +b_{10}\left(\text { Unskilled }^{*} \text { Transition }_{i}\right)+b_{11}\left(\text { Unskilled }_{i}\right)+b_{12}\left(\text { Transition }_{i}\right)+ \\
& +b_{13}\left(\text { Birth }_{i}\right)+\text { OZ }_{i}+e_{i} .
\end{aligned}
$$

Attaining a school qualification post-Butler is defined as achieving O-levels or both O-levels and A-levels and pre-Butler as achieving a Certificate of Education or both a Certificate and a Higher Certificate. For convenience in the reported regressions, we label both sets of qualifications as A/O levels. Actually, the relevant question in the BHPS asks respondents to report their highest qualifications. Therefore, we include those holding university first and higher degrees in $Q_{i}$ since, in both eras, entry into University was predicated on good performances in the two levels of school examinations.

Notice that $a_{1}, a_{7}, b_{1}$ and $b_{7}$ are the (causal) coefficients of interest. They measure the impact of family background on children's outcomes after the Butler Act came into force. In both equations, $a_{4}, a_{10}$ and $b_{4}, b_{10}$ capture the effects of the transitory period from 1944 to 1947 . This causal

\footnotetext{
${ }^{24}$ These are included as linear trends for parsimony.
} 
interpretation follows directly from differences-in-difference framework upon which our models are based.

We estimate an additional DD regression based on the structure of (1) and (2) in which parental qualification replaces father's occupation as a proxy for family background. Thus, we replace Skilled $_{i}$ and Unskilled $_{i}$ in regressions (1) and (2) with Noqual $_{i}$, a binary variable indicating no parental qualifications with the reference category consisting of at least one parent holding a qualification.

Finally, we estimate triple DD regressions in which family background (i.e., father's occupation and parental qualifications) are interacted with respondents' gender to investigate whether family background has a bearing on schooling outcomes that are systematically different for males or females.

\section{Findings}

We find that there are no statistical differences in the probability of attending a grammar school among the birth cohorts before and after the Butler reforms. This is true in respect of both the post-1944 short term transition period and the subsequent period to the mid-1960s. Table 3 shows that there are no differences between children with fathers in either skilled or unskilled occupations compared with fathers in professional and managerial occupations, between children with parents who have no qualifications and those with at least one parent with qualifications. Findings of no significant breaks in the probabilities of attending a grammar school generally remain when we test the two types of parental background conditional on whether the school pupil was a boy or a girl. As shown in Table 4, this is unequivocally the case after incorporating our full set of control variables. Note that in the latter case, the estimated coefficients are also small in size. 
We then repeated these DD regressions after replacing the dependent variable 'attending a grammar school' with 'achieving an O-level or A-level qualification'. ${ }^{25}$ When father's occupation, and parental qualifications are tested separately, we obtain comparable findings to those with respect to grammar school entry. As shown in Table 5, we obtained no statistically significant interaction terms. However, extending the qualification regressions to interact gender and parental attributes does produce one change. In Table 6 , we find that in the post-transition period boys from home backgrounds in which the father is unskilled achieved a significant improvement compared with equivalent preceding cohorts in gaining qualifications. This finding is robust across the whole range of added control variables although with the strength maximised in the full specification. An equivalent result is not found in the case of girls. Nor do we find statistically significant breaks when the dependent variable, parental qualifications, replaces father's occupation.

How do we explain the apparent anomaly of boys with unskilled fathers experiencing no changed relative probability of grammar school entry while improving the probability of gaining formal school qualifications post-Butler? We know that obtaining qualifications in both eras was predicated on staying at school until at least the age of 16 . We also know that working class families could be reluctant to extend their children's secondary education beyond the legal leaving age ${ }^{26}$ due in part to foregone earnings. But the related opportunity costs of extended education were lowered postButler because the gap between age 16 and the minimum school leaving age was reduced by 1 year in 1947. So if, because of this, there were fewer early grammar school leavers post- Butler this would

\footnotetext{
${ }^{25}$ While referring in all Tables to A/O levels, these respective outcomes are taken to represent success in achieving a school Certificate or Higher Certificate in the pre-Butler era.

${ }^{26}$ The largest study, covering a 10 per cent of maintained and direct grant grammar schools in England and Wales provides extensive information on boys and girls who entered grammar school in 1946. It reveals that children from semi-skilled and unskilled parental backgrounds had much higher propensities to leave grammar school before reaching the age of 16 and obtaining a School Certificate ((Ministry of Labour, 1954 Table 7, Appendix II).
} 
help to explain the findings of unchanged grammar school entry combined with an improved incidence of pupils gaining grammar school qualifications.

Table 8 shows the percentages of boys and girls leaving grammar school by age in our sample. We find that $21 \%$ of boys with unskilled fathers left school at 15 in both eras. This compares with $15 \%$ of boys with skilled fathers on only $6 \%$ with professional/managerial fathers. ${ }^{27}$ However, we find that a further $23 \%$ left school at 14 in the pre-Butler period compared with, respectively, $9 \%$ and $8 \%$ in the other two groups. For girls with the same background, $26 \%$ and $20 \%$ left school at age 15 pre- and post-Butler respectively, but only $9 \%$ left school at 14 in the pre-Butler era.

We add two notes of caution concerning these latter regression findings. First, they are based on relatively small sample sizes of children from unskilled households who attended grammar schools. Second, these effects could be attributed to pre-trends. In the following section, we find some evidence of this.

\section{Robustness checks}

We carried out a series of robustness checks of these findings.

We include indicators modelling the probability of attending grammar school and obtaining school qualification by father's occupation and parental education for each 3-year birth cohorts from 1915 to 1953 . This approach enhances the analysis in two ways. First, the birth cohort indicators preButler provide evidence of the common trend assumption. If the control and treatment groups are comparable, we would expect the coefficients on the indicators of cohorts born prior to the reform being not statistically different from zero. Our analysis however does show an effect only for males

${ }^{27}$ In their in-depth study of four London boys' grammar schools, Halsey and Gardner (1953, Figure II) report on the preferred school leaving ages of pupils, fathers and mothers. Middle class boys and their parents reported higher preferences to stay beyond the age of 16 while working class boys and their parents reported higher preferences to leave school before the age of 16. The BHPS outcomes in Table 8 are generally consistent with these reported preferences. 
with unskilled fathers, so particularly interesting would be to control for pre-trends for this category. Second, and perhaps more important for us, the 3-year birth cohorts of individuals born after the reform relax the implicit assumption, common to standard DD estimators, of constant treatment effects. This will enable us to look at the dynamics, i.e., short and long run effects of the reform. Previous analysis focussing on the mean shift might fail to detect these dynamics. This analysis is interesting in its own right, even in the absence of common trends, because it focuses on the evolution of the reform for different birth cohorts.

We exclude the cohort born in the period 1930-1933 (i.e., the last cohort not affected by the reform), so that coefficients measure the dynamics relative to this period. ${ }^{28}$ The coefficients for grammar attendance and school qualification, together with $95 \%$ confidence level, are plotted in Figures 7 and 8 (respectively).

Concerning the probability of attending grammar school, the overall dynamic provides clear evidence that there is not a big difference in outcomes between pre- and post-Butler across our groups. These plots confirm that the chance of gaining a qualification was higher for pupils with unskilled fathers, but also indicate that this chance was higher even before the reform for cohorts of children born between 1924 and 1929. This underscores our need for caution in respect of interpreting our results in respect of boys with unskilled fathers, signalled in the previous section. The analysis also shows that cohorts of children with skilled fathers born after 1940 to 1946 improved their chances of gaining qualifications.

Further, and in respect to the qualifications-regressions, the investigation into the dynamics provide a robustness check for different definitions of transition period. For example, a longer transition period from 1928 to 1936 would capture instances of pupils who were already at grammar school in 1944 (aged 12 to 16) and whose LEA made free education available thereby increasing the

\footnotetext{
${ }^{28}$ Choosing an earlier birth cohort does not affect our conclusions.
} 
probability that there were cases who gained O-level qualifications who otherwise would have left school prematurely. In the event, our estimates revealed no substantive differences to any of our core results. Similarly, this dynamic analysis can be seen as allowing for an extended post-1944 transition period since we do not know precisely when the Butler reforms became, more or less, fully operational. None of these additional regressions had implications for our earlier reported findings.

\section{Concluding remarks}

Our evidence in respect of both the pre- and post- Butler eras is consistent, for both boys and girls, with one of the main conclusions of an extensive study of children who entered 120 grammar schools in England and Wales in 1946. It states that “...it is beyond doubt true that a boy whose father is of professional or managerial standing is more likely to find his home circumstances favourable to the demands of grammar school work than one whose father is an unskilled or semiskilled worker" (Ministry of Labour, 1954). We find that the advantages of children from middle class homes in gaining both grammar school places and formal school qualifications at ages 16 and 18 remained about the same whether free school places were either partially or fully financed by the state. The introduction of completely free secondary school education in 1944 did not lead, for the large part, to state selective schools becoming an improved vehicle for social mobility. 


\section{References}

Angrist, Joshua D. and Jörn-Steffen Pischke. 2009. Mostly Harmless Econometrics, Princeton, University Press.

Banks, James, and Fabrizio Mazzona. 2012. The effect of education on old age cognitive abilities: evidence from a regression discontinuity design. Economic Journal, 122, 418-448.

Board of Education. 1938. Education in 1937. Cmd. 5776, London: HMSO

Bolton, Paul. 2013. Grammar school statistics. House of Commons Library: SN/SG/1398.

Brunello, Giorgio and Daniele Checchi. 2003. School Quality and Family Background in Italy. IZA DP No. 705.

Cameron, Colin and Pravin K. Trivedi. 2005. Microeconometrics: methods and applications. Cambridge university press.

Chevalier, Arnaud, Colm Harmon, Vincent O'Sullivan, and Ian Walker. 2010. The impact of parental income and education on the schooling of their children. UCD Geary Institute Discussion Paper Series, WP 1032.

Clark, Damon. 2010. Selective schools and academic achievement. The B.E. Journal of Economic Analysis and Policy, 1-40.

Clark, Damon and Del Bono, Emilia. 2014. The long-run effects of attending an elite school: evidence from the UK. ISER Working Paper Series 2014-05.

Clark, Damon, and Heather Royer. 2013. The Effect of Education on Adult Mortality and Health: Evidence from Britain. American Economic Review, 103(6): 2087-2120.

Dent, Harold C. 1954. Growth in English education, 1946-1952. London: Routledge and Kegan Paul.

Devereux, Paul J, and Robert A. Hart. 2010. Forced to by rich? Returns to compulsory schooling in Britain. Economic Journal, 120, 1345-1364.

Dustmann, Christian. 2004. Parental background, secondary school track choice, and wages. Oxford Economic Papers 56, 209-230.

Drake, Barbara. 1939. The Spens Report. Political Quarterly 10, 215-233.

Ermisch, John and Marco Francesconi. 2001. Family matters: impacts of family background on educational attainments. Economica, 68, 137 - 156.

Floud, Jean. 1954. The education experience of the adult population of England and Wales at July 1949. In D.V. Glass (ed.), Social Mobility in Britain, London: Routledge and Kegan Paul Ltd.

Glass, D.V. and J.R.Hall. 1954. A description of a sample inquiry into social mobility in Great Britain. In D.V. Glass (ed.), Social Mobility in Britain, London: Routledge and Kegan Paul Ltd. 
Hadow Report. 1926. The education of the adolescent. London: HM Stationary Office.

Halsey, A H and L Gardner. 1953. Selection for secondary education and achievement in four grammar schools. British Journal of Sociology, 4, 60 - 75.

Halsey, A H, A F Heath, and J M Ridge. 1980. Origins and destinations. Family, class, and education in modern Britain. Oxford: Clarendon Press.

Harmon Colm and Ian Walker. 1995. Estimates of the Economic Return to Schooling for the United Kingdom. American Economic Review 85, 1278-1296.

Heim, Alice W. 1954. The appraisal of intelligence. London: National Foundation for Educational Research in England and Wales.

Imbens, Guido W. 2004. Nonparametric estimation of average treatment effects under exogeneity: A review. Review of Economics and Statistics, (86)1: 4-29.

Imbens, Guido W., and Jeffrey M. Wooldridge. 2009. Recent Developments in the Econometrics of Program Evaluation. Journal of Economic Literature, 47(1): 5-86.

Lauer, Charlotte. 2012. Family Background, Cohort and Education: A French-German Comparison. ZEW DP No. 02-12.

Lindsay, Kenneth. 1926. Social Progress and Educational Waste. London: Routledge.

Martin, F M. 1954. An enquiry into parents' preferences in secondary education. In Glass, D V (editor), Social Mobility in Britain. London: Routledge and Kegan Paul.

Ministry of Education. 1954. Early leaving. London: HMSO.

Mitchell, Brian R. 1988. British historical statistics. Cambridge: Cambridge University Press.

Norwood Report. 1943. Curriculum and examinations in secondary schools. London: HM Stationary Office.

Oreopoulos, Philip. 2006. Estimating Average and Local Average Treatment Effects of Education When Compulsory Schooling Laws Really Matter, American Economic Review 96, 152-175.

Pop-Eleches, C. and M. Urquiola, (2013), Going to Better Schools: Effects and Behavioral Responses, American Economic Review, 103(4): 1289-1324.

Powdthavee, Nattavudh. 2010. Does Education Reduce the Risk of Hypertension? Estimating the Biomarker Effect of Compulsory Schooling in England. Journal of Human Capital 4, $173-$ 202.

Plug, Erik and Wim Vijverberg. 2001. Schooling Family, Background and Adoption: Does Family Income Matter? IZA DP No. 246.

Routh, Guy. 1980. Occupation and pay in Great Britain, 1906-1979. London, Macmillan. 
Rubinstein, David and Brian Simon. 1969. The evolution of the comprehensive school, 1926-1966. London: Routledge and Kegan Paul.

Spens Report. 1938. Secondary Education with Special Reference to Grammar Schools and Technical High Schools. London: HM Stationery Office

Sumner, Claudia. 2010. 1945-1965: the long road to Circular 10/65. Reflecting Education, 6, 90 - 102.

Vernon, P E. 1957. Secondary school selection. London: Methuen.

Woessmann, Ludger. 2004. How Equal Are Educational Opportunities? Family Background and Student Achievement in Europe and the United States. IZA DP No. 1284.

Woessmann, Ludger. 2005. Families, Schools, and Primary-School Learning: Evidence for Argentina and Colombia in an International Perspective. World Bank Policy Research Paper 3537. 
Table 1 Number of pupils aged 10/11 and over on school registers in March 1937

\begin{tabular}{lccccc}
\hline \hline Age & Elementary & $\begin{array}{c}\text { Grant-aided } \\
\text { Secondary }\end{array}$ & $\begin{array}{c}\text { Junior } \\
\text { Technical } \\
\text { etc. } \\
(1)\end{array}$ & Total & $\begin{array}{c}\text { Estimated } \\
\text { population } \\
\text { (thousands) }\end{array}$ \\
\hline $\mathbf{1 0}-\mathbf{1 1}$ & 566,964 & 12,165 & - & 579,129 & 613 \\
$\mathbf{1 1}-\mathbf{1 2}$ & 552,388 & 44,536 & - & 596,924 & 629 \\
$\mathbf{1 2}-\mathbf{1 3}$ & 522,304 & 80,154 & 1,135 & 603,593 & 641 \\
$\mathbf{1 3}-\mathbf{1 4}$ & 530,122 & 83,902 & 4,886 & 618,910 & 658 \\
$\mathbf{1 4}-\mathbf{1 5}$ & 158,303 & 79,390 & 11,401 & 249,094 & 681 \\
$\mathbf{1 5}-\mathbf{1 6}$ & 19,743 & 73,333 & 9,037 & 102,113 & 728 \\
$\mathbf{1 6} \mathbf{- 1 7}$ & 2,393 & 47,718 & 2,972 & 53,083 & 770 \\
$\mathbf{1 7 +}$ & - & 27,670 & 330 & 28,000 & $2,413(2)$ \\
Total & $2,352,217$ & 448,868 & 29,761 & $2,830,846$ & - \\
\hline \hline
\end{tabular}

Source: Board of Education (1938), Table 2, p. 89.

(1) Junior technical and commercial schools, junior housewifery schools, junior departments in art schools, schools of nautical training.

(2) Above 17 and under 21. 
Table 2 Percentages attending different types of secondary schools in the BHPS samples

\begin{tabular}{lcc}
\hline \hline & Born $<\mathbf{1 9 3 6}$ & Born $\geq \mathbf{1 9 3 6}$ \\
\hline Grammar & $20.10^{1}$ & 23.15 \\
Elementary & $58.12^{2}$ & - \\
Secondary Modern & - & $51.24^{4}$ \\
Technical & 2.79 & 3.43 \\
Public and other private & 5.06 & 5.27 \\
Other & 10.22 & 2.54 \\
Unallocated & $3.71^{3}$ & $14.37^{5}$ \\
Total (individuals) & 3259 & 3585 \\
\hline \hline
\end{tabular}

\section{Notes:}

1. Includes respondents who left school at 16 to 18 who indicated that they went to secondary/secondary modern school and who were born before 1936.

2. Includes respondents who left school at 13 to 15 who indicated that they went to secondary/secondary modern school and who were born before 1936.

3. Consists of respondents who indicated that they attended comprehensive school and who were born before 1936.

4. Includes respondents who indicated that they attended elementary school and who were born at or later than 1936.

5. Consists of those who indicated that they attended comprehensive school. 
Table 3 Difference-in-difference estimates of probability of attending a grammar school by family background

\begin{tabular}{|c|c|c|c|c|}
\hline \multirow{3}{*}{ (Reference group) } & \multirow{2}{*}{\multicolumn{2}{|c|}{$\begin{array}{c}\text { Father's occupation } \\
\text { (Fathers in professional or } \\
\text { managerial occupations) }\end{array}$}} & \multirow{2}{*}{\multicolumn{2}{|c|}{$\begin{array}{c}\text { Parental education } \\
\text { (At least one parent with } \\
\text { qualification) } \\
\end{array}$}} \\
\hline & & & & \\
\hline & $(1)$ & $(2)$ & (3) & (4) \\
\hline \multirow[t]{2}{*}{$($ Skilled $) *($ Transition $)$} & -0.060 & -0.016 & & \\
\hline & $(0.074)$ & $(0.122)$ & & \\
\hline \multirow[t]{2}{*}{ (Unskilled)*(Transition) } & -0.060 & 0.142 & & \\
\hline & $(0.039)$ & $(0.126)$ & & \\
\hline \multirow[t]{2}{*}{$($ Skilled $) *($ Post $)$} & 0.018 & 0.065 & & \\
\hline & $(0.032)$ & $(0.058)$ & & \\
\hline \multirow[t]{2}{*}{$($ Unskilled $) *($ Post $)$} & 0.013 & 0.084 & & \\
\hline & $(0.032)$ & $(0.056)$ & & \\
\hline \multirow[t]{2}{*}{$($ Noqual $) *($ Transition $)$} & & & -0.005 & -0.029 \\
\hline & & & $(0.045)$ & $(0.078)$ \\
\hline \multirow[t]{2}{*}{ (Noqual)*(Post) } & & & 0.029 & -0.015 \\
\hline & & & $(0.030)$ & $(0.034)$ \\
\hline Observations & 5,537 & 2,412 & 6,306 & 2,652 \\
\hline R-squared & 0.058 & 0.122 & 0.015 & 0.109 \\
\hline Year of birth fixed effects & Yes & Yes & Yes & Yes \\
\hline Individual characteristics & No & Yes & No & Yes \\
\hline Parental year of birth & No & Yes & No & Yes \\
\hline Others & No & Yes & No & Yes \\
\hline
\end{tabular}

Notes: Robust standard errors in parentheses (clustered at year of birth) $* * * p<0.01, * * p<0.05$, * $\mathrm{p}<0.1$ Individual characteristics: gender, birth order in family, district of birth. Parental year of birth: mother and father's year of birth (linear trends). Other controls: books at home, area where born. 
Table 4 Triple difference-in-difference estimates of probability of attending a grammar school by gender and family background

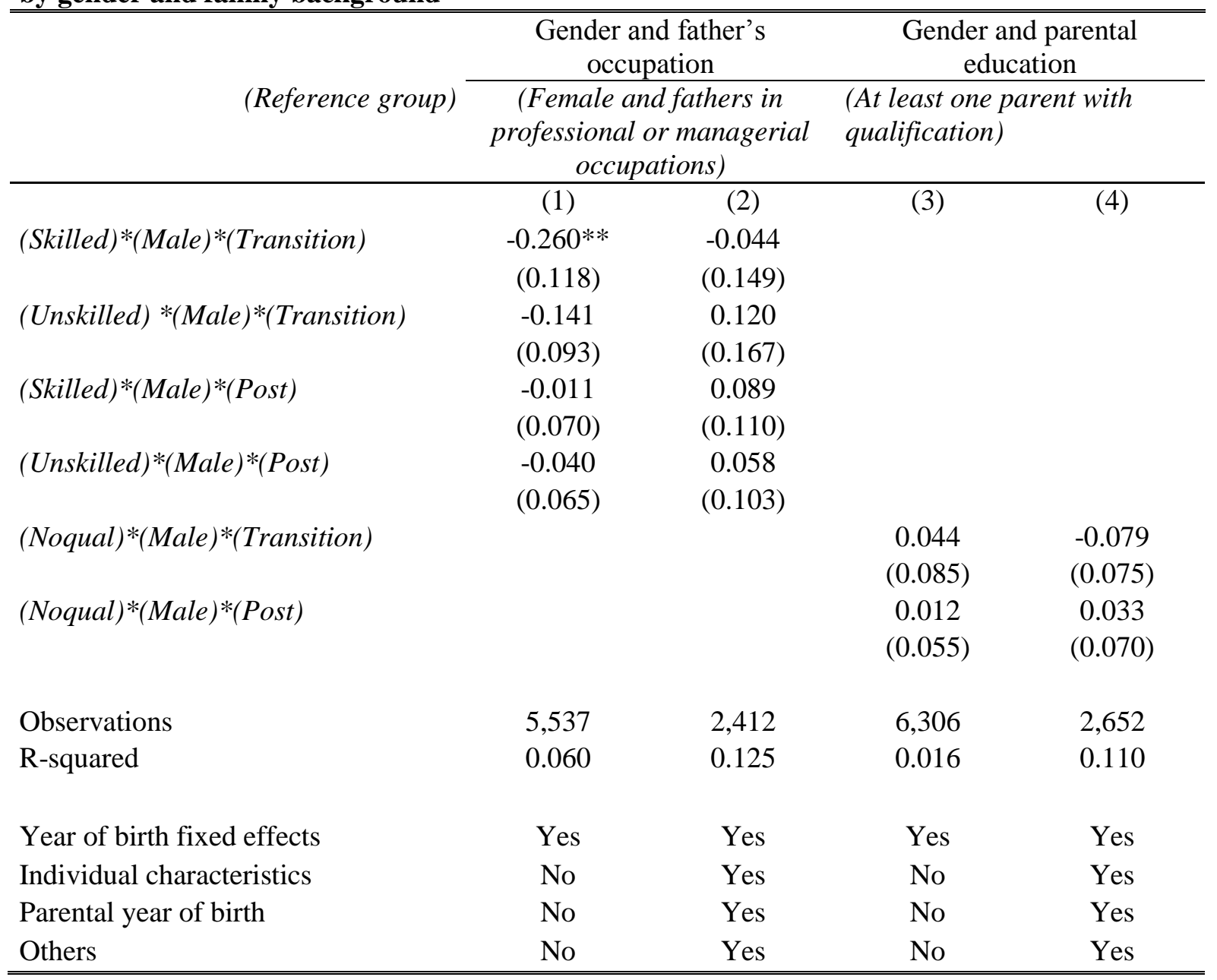

Notes: Robust standard errors in parentheses (clustered at year of birth) $* * * p<0.01, * * p<0.05, *$ $\mathrm{p}<0.1$ Individual characteristics: gender, birth order in family, district of birth. Parental year of birth: mother and father's year of birth (linear trends). Other controls: books at home, area where born. 
Table 5 Difference-in-difference estimates of probability of attaining formal school qualifications by family background

\begin{tabular}{|c|c|c|c|c|}
\hline \multirow{3}{*}{$\begin{array}{l} \\
\end{array}$} & \multicolumn{2}{|c|}{ Father's occupation } & \multicolumn{2}{|c|}{ Parental education } \\
\hline & \multicolumn{2}{|c|}{$\begin{array}{c}\text { (Fathers in professional or } \\
\text { managerial occupations) }\end{array}$} & \multicolumn{2}{|c|}{$\begin{array}{c}\text { (At least one parent with } \\
\text { qualification) }\end{array}$} \\
\hline & $(1)$ & $(2)$ & $(3)$ & (4) \\
\hline \multirow[t]{2}{*}{ (Skilled)*(Transition $)$} & -0.021 & -0.065 & & \\
\hline & $(0.050)$ & $(0.075)$ & & \\
\hline \multirow[t]{2}{*}{ (Unskilled)*(Transition) } & -0.009 & 0.070 & & \\
\hline & $(0.055)$ & $(0.095)$ & & \\
\hline \multirow[t]{2}{*}{$($ Skilled $) *($ Post $)$} & 0.004 & 0.001 & & \\
\hline & $(0.024)$ & $(0.053)$ & & \\
\hline \multirow[t]{2}{*}{$($ Unskilled $) *($ Post $)$} & -0.022 & 0.019 & & \\
\hline & $(0.027)$ & $(0.048)$ & & \\
\hline \multirow[t]{2}{*}{$($ Noqual $) *($ Transition $)$} & & & 0.021 & 0.036 \\
\hline & & & $(0.019)$ & $(0.046)$ \\
\hline \multirow[t]{2}{*}{ (Noqual)*(Post) } & & & 0.032 & -0.031 \\
\hline & & & $(0.028)$ & $(0.047)$ \\
\hline Observations & 5,509 & 2,394 & 6,276 & 2,634 \\
\hline R-squared & 0.072 & 0.114 & 0.044 & 0.114 \\
\hline Year of birth fixed effects & Yes & Yes & Yes & Yes \\
\hline Individual characteristics & No & Yes & No & Yes \\
\hline Parental year of birth & No & Yes & No & Yes \\
\hline Others & No & Yes & No & Yes \\
\hline
\end{tabular}

Notes: Robust standard errors in parentheses (clustered at year of birth) $* * * p<0.01, * * p<0.05$, * $\mathrm{p}<0.1$ Individual characteristics: gender, birth order in family, district of birth. Parental year of birth: mother and father's year of birth (linear trends). Other controls: books at home, area where born. 
Table 6 Triple difference-in-difference estimates of probability of attaining formal school qualifications by gender and family background

\begin{tabular}{|c|c|c|c|c|}
\hline \multirow{3}{*}{ (Reference group) } & \multirow{2}{*}{\multicolumn{2}{|c|}{$\begin{array}{c}\text { Gender and father's } \\
\text { occupation } \\
\text { (Female and fathers in } \\
\text { professional or managerial } \\
\text { occupations) }\end{array}$}} & \multirow{2}{*}{\multicolumn{2}{|c|}{$\begin{array}{l}\begin{array}{l}\text { Gender and parental } \\
\text { education }\end{array} \\
\text { (At least one parent with } \\
\text { qualification) }\end{array}$}} \\
\hline & & & & \\
\hline & $(1)$ & (2) & (3) & (4) \\
\hline \multirow[t]{2}{*}{$($ Male $) *($ Skilled $) *($ Transition $)$} & 0.006 & 0.013 & & \\
\hline & $(0.079)$ & $(0.096)$ & & \\
\hline \multirow[t]{2}{*}{$($ Male $) *($ Unskilled $) *($ Transition $)$} & 0.163 & $0.267 *$ & & \\
\hline & $(0.118)$ & $(0.154)$ & & \\
\hline \multirow[t]{2}{*}{$($ Male $) *($ Skilled $) *($ Post $)$} & 0.065 & 0.143 & & \\
\hline & $(0.069)$ & $(0.098)$ & & \\
\hline \multirow[t]{2}{*}{$($ Male $) *($ Unskilled $) *($ Post $)$} & $0.175^{* *}$ & $0.302 * *$ & & \\
\hline & $(0.066)$ & $(0.113)$ & & \\
\hline \multirow[t]{2}{*}{$($ Male $) *($ Noqual $) *($ Transition $)$} & & & $0.150^{* *}$ & 0.099 \\
\hline & & & $(0.063)$ & $(0.161)$ \\
\hline \multirow[t]{2}{*}{$($ Male $) *($ Noqual $) *($ Post $)$} & & & -0.067 & -0.094 \\
\hline & & & $(0.042)$ & $(0.062)$ \\
\hline Observations & 5,509 & 2,394 & 6,276 & 2,634 \\
\hline R-squared & 0.074 & 0.118 & 0.045 & 0.116 \\
\hline Year of birth fixed effects & Yes & Yes & Yes & Yes \\
\hline Individual characteristics & No & Yes & No & Yes \\
\hline Parental year of birth & No & Yes & No & Yes \\
\hline Others & No & Yes & No & Yes \\
\hline
\end{tabular}

Notes: Robust standard errors in parentheses (clustered at year of birth) $* * * \mathrm{p}<0.01, * * \mathrm{p}<0.05, *$ $\mathrm{p}<0.1$ Individual characteristics: gender, birth order in family, district of birth. Parental year of birth: mother and father's year of birth (linear trends). Other controls: books at home, area where born. 
Table 7 Average pay by male occupation class as a percentage of the simple average of all men (= 100). 1922-4 to 1960

\begin{tabular}{lcccc}
\hline \hline Occupation Class & $\mathbf{1 9 2 2 - 4}$ & $\mathbf{1 9 3 5 - 6}$ & $\mathbf{1 9 5 5 - 6}$ & $\mathbf{1 9 6 0}$ \\
\hline \hline Professional and Managerial & & & & \\
Higher Professional & 206 & 220 & 191 & 195 \\
Lower Professional & 113 & 107 & 75 & 81 \\
Managers etc. & 169 & 153 & 183 & 177 \\
Skilled (manual/non-manual & & & & \\
Manual skilled & 64 & 68 & 77 & 76 \\
Foremen & 95 & 95 & 97 & 76 \\
Clerks & 64 & 68 & 77 & 56 \\
Semi-skilled and Unskilled & 44 & 46 & 58 & 51 \\
Semi-skilled & 45 & 45 & 54 & 100 \\
Unskilled & 100 & 100 & 100 & \\
All & & & & \\
\hline \hline Routh (1980: Tee Tabl 230 & & & & \\
\hline
\end{tabular}

Routh (1980: see Table 2.30, p. 127) 
Table 8 Age left grammar school by father's occupation (\%)

\begin{tabular}{|c|c|c|c|c|c|c|c|c|c|c|c|c|c|c|c|c|}
\hline & \multicolumn{8}{|c|}{ Male } & \multicolumn{8}{|c|}{ Female } \\
\hline & \multicolumn{7}{|c|}{ Age left school } & \multirow[t]{2}{*}{$\begin{array}{c}\text { Sample } \\
\text { size }\end{array}$} & \multicolumn{7}{|c|}{ Age left school } & \multirow[t]{2}{*}{$\begin{array}{c}\text { Sample } \\
\text { size }\end{array}$} \\
\hline & $\leq 13$ & $\underline{14}$ & $\underline{15}$ & $\underline{16}$ & $\underline{17}$ & $\underline{18}$ & $\underline{19}$ & & $\leq 13$ & $\underline{14}$ & $\underline{15}$ & $\underline{16}$ & $\underline{17}$ & $\underline{18}$ & $\underline{19}$ & \\
\hline \multicolumn{17}{|l|}{ Pre-Butler } \\
\hline$\overline{\text { Professional }}$ & 2 & 8.2 & 16.3 & 33.7 & 18.4 & 17.3 & 4.1 & 98 & - & 3.1 & 11.2 & 30.6 & 27.6 & 24.5 & 3.1 & 98 \\
\hline Skilled & - & 9 & 17.3 & 50.4 & 11.3 & 10.5 & 1.5 & 133 & - & 7.1 & 22.9 & 40 & 15.7 & 13.6 & 0.7 & 140 \\
\hline Unskilled & - & 22.9 & 20.8 & 29.2 & 10.4 & 14.6 & 2.1 & 48 & - & 8.5 & 25.5 & 36.2 & 12.8 & 17 & - & 47 \\
\hline \multicolumn{17}{|l|}{ Post-Butler } \\
\hline Professional & - & - & 5.6 & 23.6 & 18.1 & 43.8 & 9 & 144 & - & - & 5.5 & 33.8 & 17.2 & 42.1 & 1.4 & 145 \\
\hline Skilled & - & 1 & 14.6 & 33 & 23.3 & 26.2 & 1.9 & 206 & 0.5 & 0.9 & 13 & 45.4 & 15.7 & 23.1 & 1.4 & 216 \\
\hline Unskilled & - & 1.8 & 21.1 & 38.6 & 14 & 19.3 & 5.3 & 57 & - & 1.2 & 20 & 41.2 & 12.5 & 23.8 & 1.2 & 80 \\
\hline
\end{tabular}

Notes: Proportion of pupils leaving school by age and parental background (father's occupation). BHPS sample. 
Figure 1 Numbers of boys and girls entered for School Certificate and Higher Certificate: $1924 / 5$ to $1936 / 7$

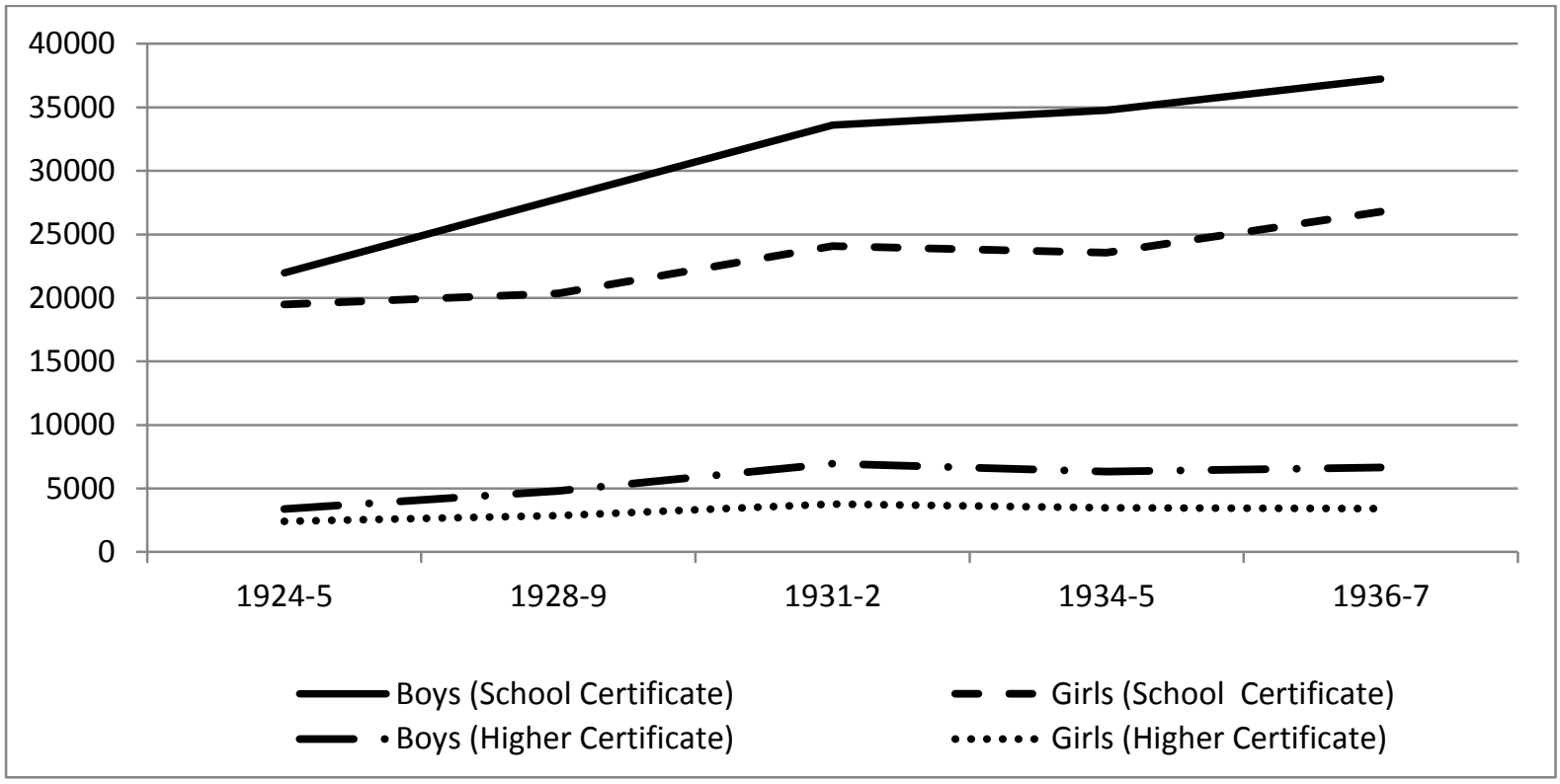

Source: Spens Report (1938), Chapter II, Tables 11 and 12

Figure 2 Birth registrations and BHPS sample birth cohorts in England and Wales from 1906 to 1953 


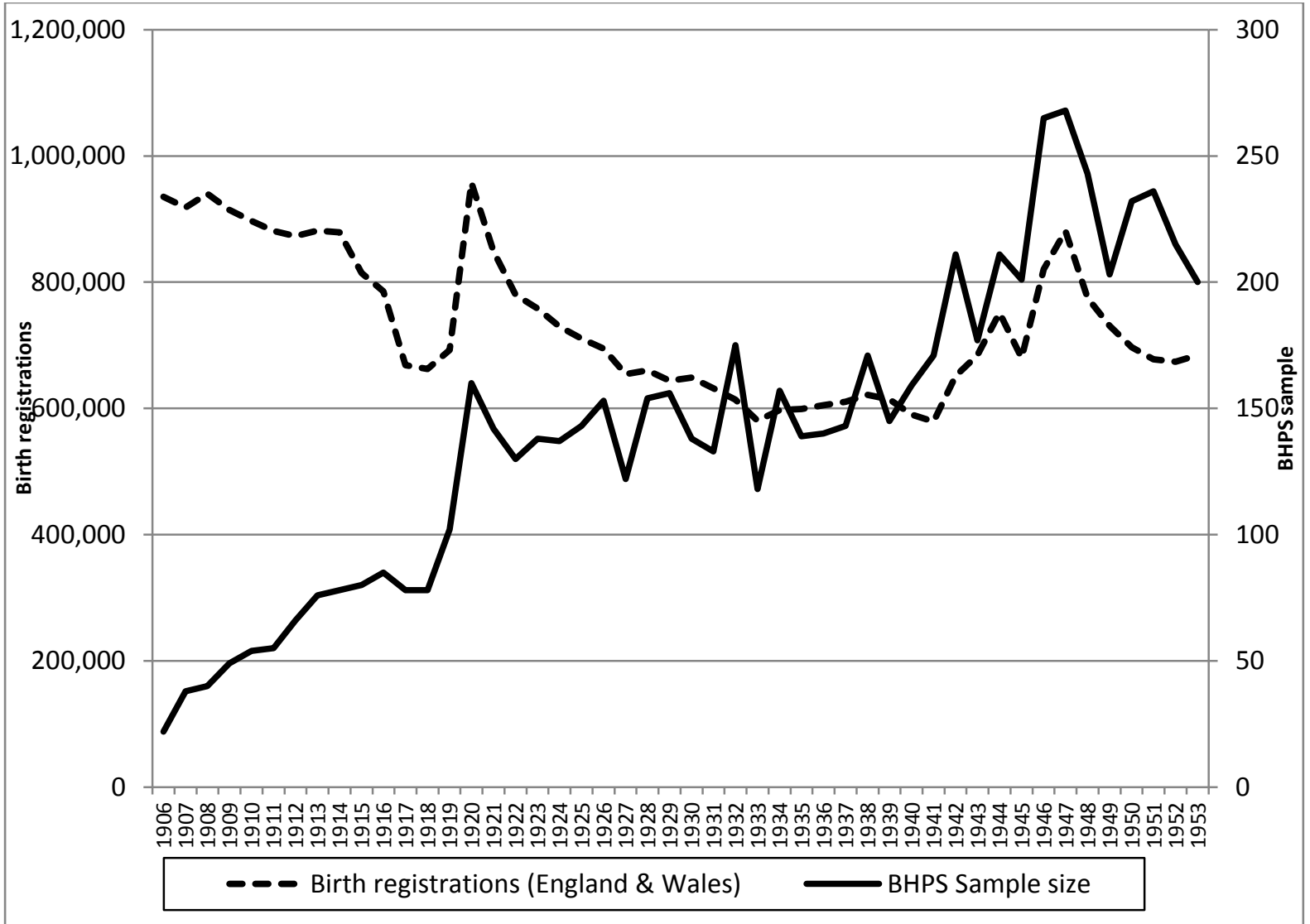


Figure 3 Proportion of grammar school males by father's occupation class

( 3 year moving average by year of birth)

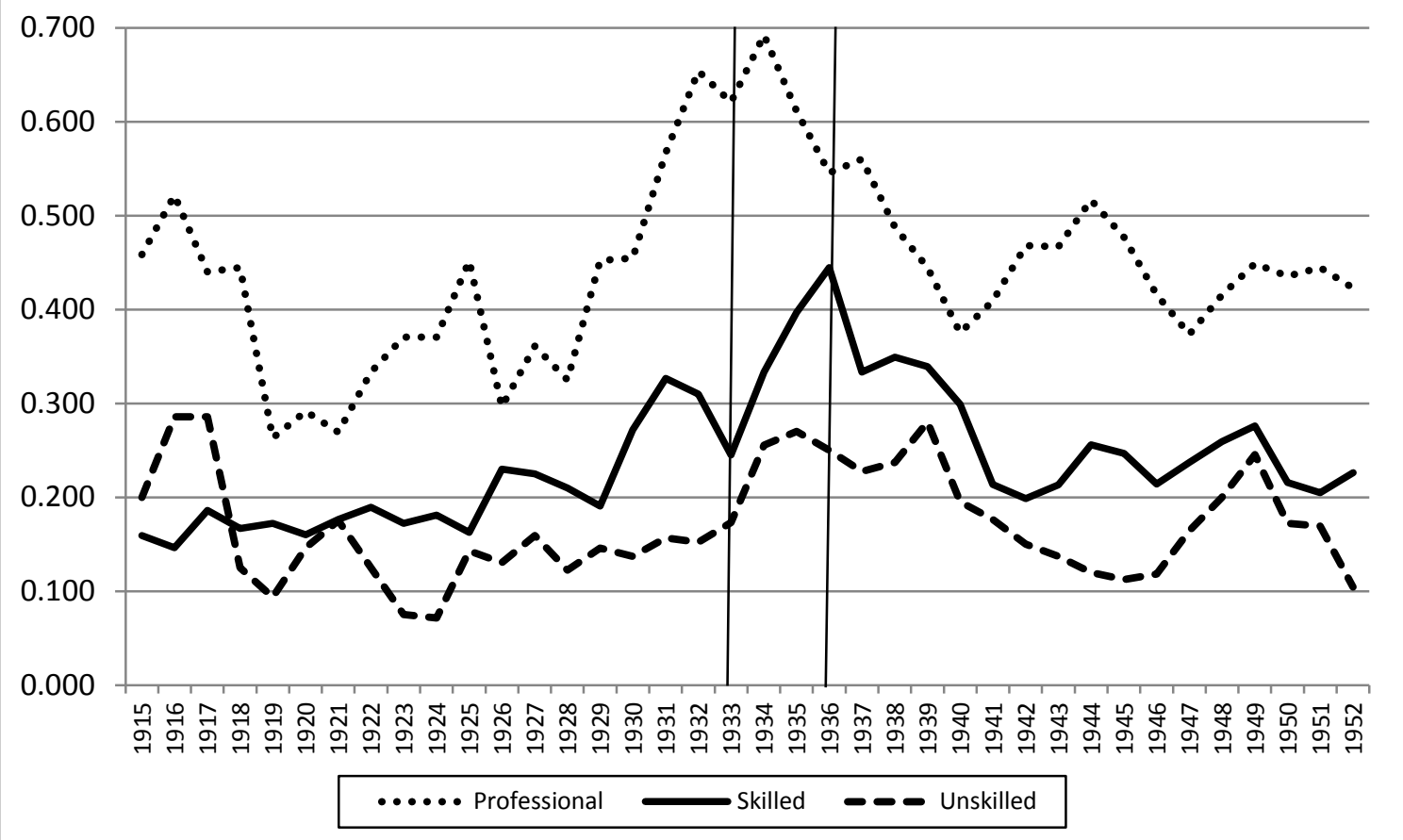


Figure 4 Proportion of grammar school females by father's occupation class

( 3 year moving average by year of birth)

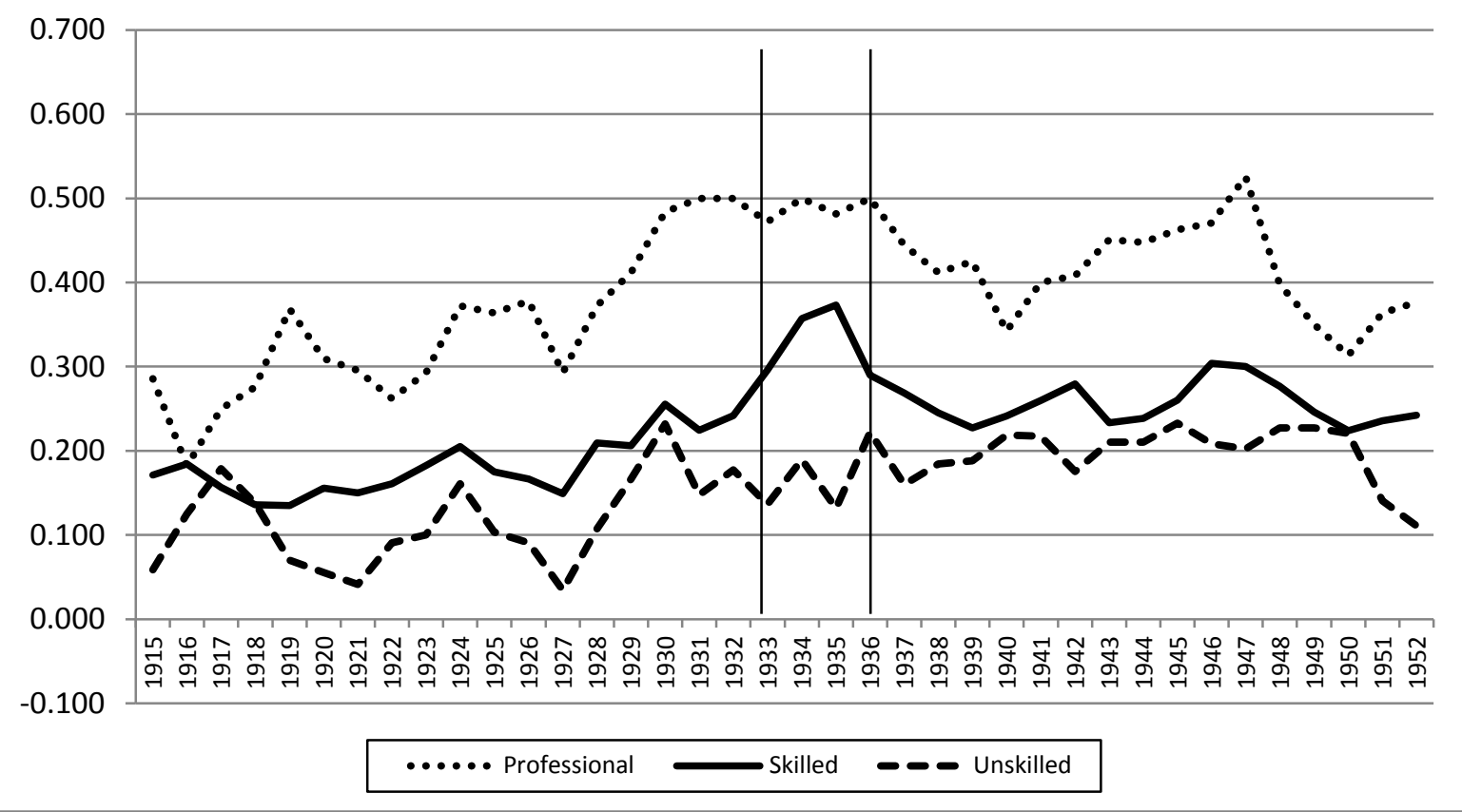

Figure 5 Proportion of grammar school males who achieved A/O levels by father's occupation class

( 3 year moving average by year of birth)

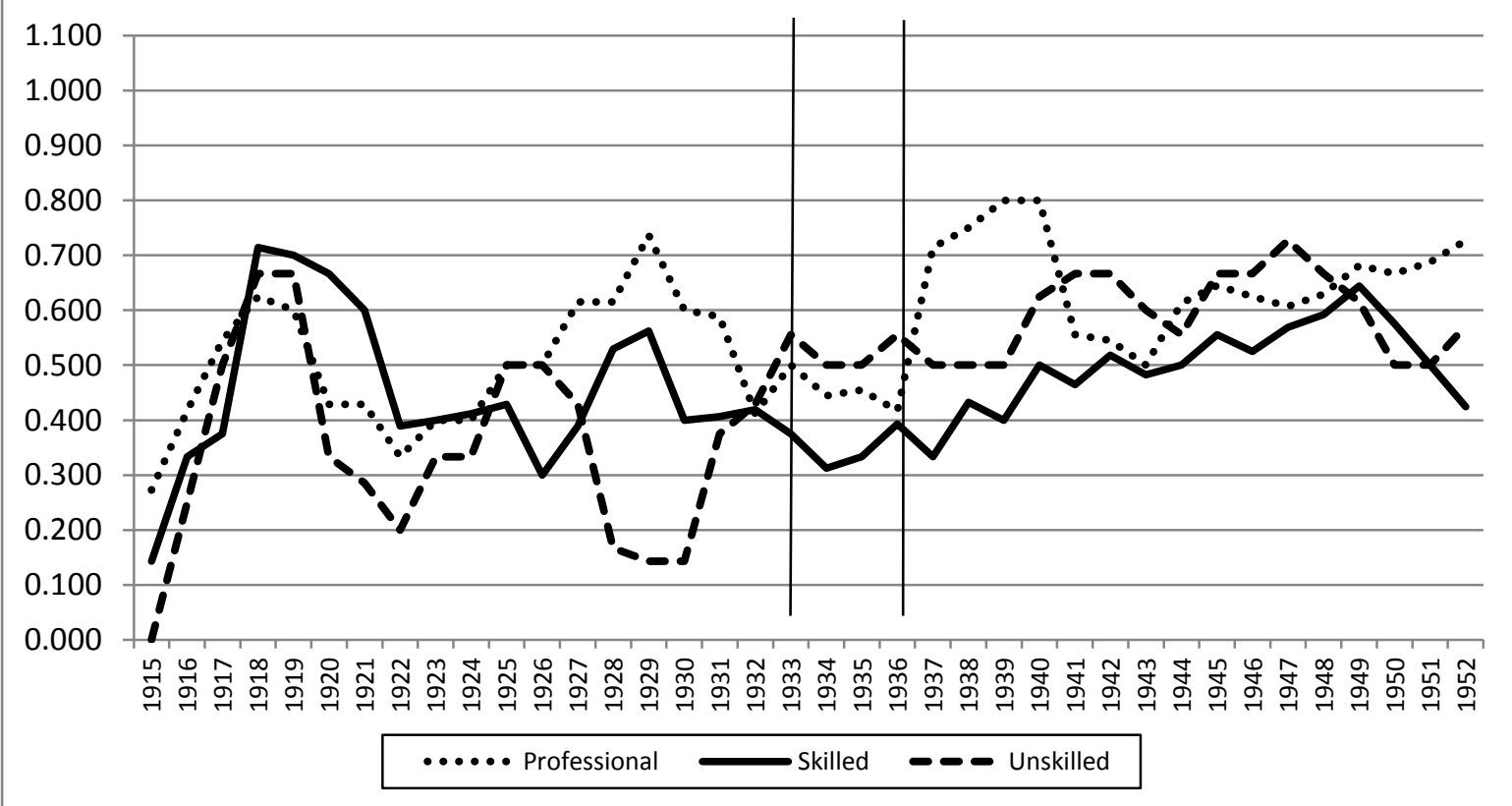


Figure 6 Proportion of grammar school females who achieved A/O levels by father's occupation class

( 3 year moving average by year of birth)

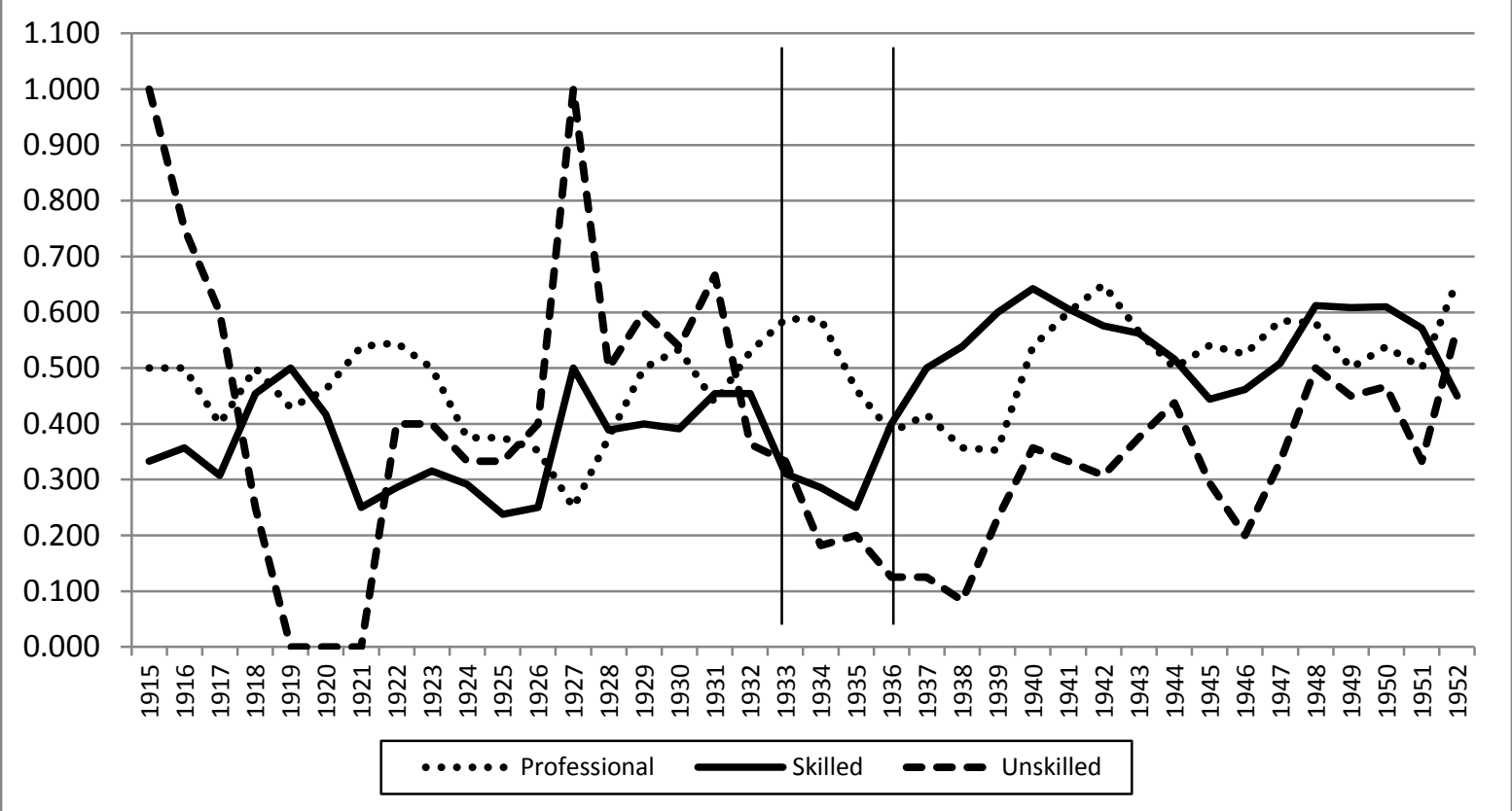


Figure 7 The probability of going to grammar school by birth cohorts around the reform classified by gender, father's occupation and parental education
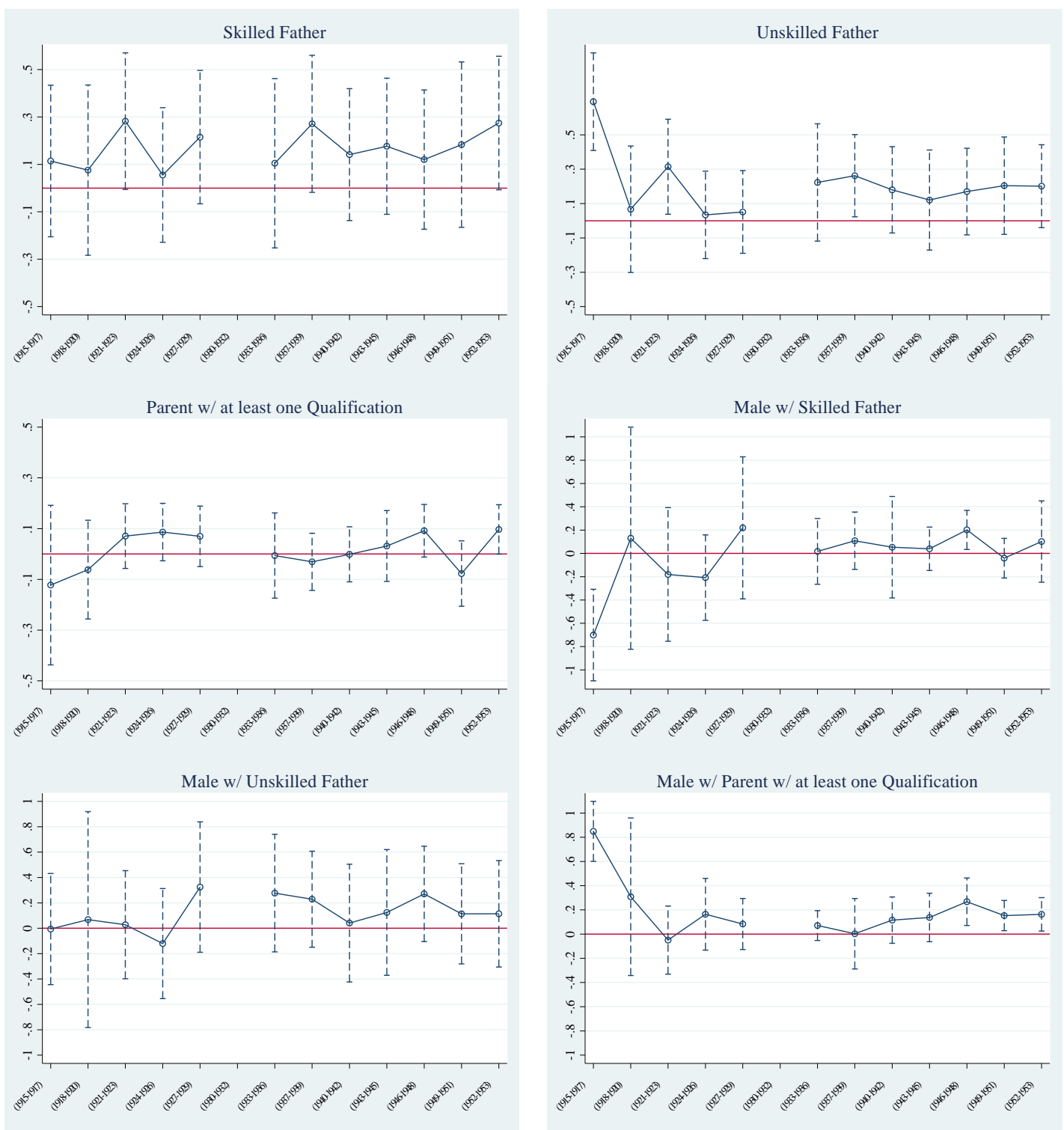

Notes: The figure plots coefficients from linear probability regressions of going to grammar school on 3-year birth cohort indicator variables. The 3-year birth cohort variable (1930-1933) is omitted, so that coefficients are measured relative to this cohort. Year of birth fixed effects, individual characteristics and parental year of birth are included in each regression. The dashed lines present $95 \%$ confidence intervals, with standard errors clustered by year of birth. 
Figure 8 The probability of obtaining qualifications by birth cohorts around the reform classified by gender, father's occupation and parental education
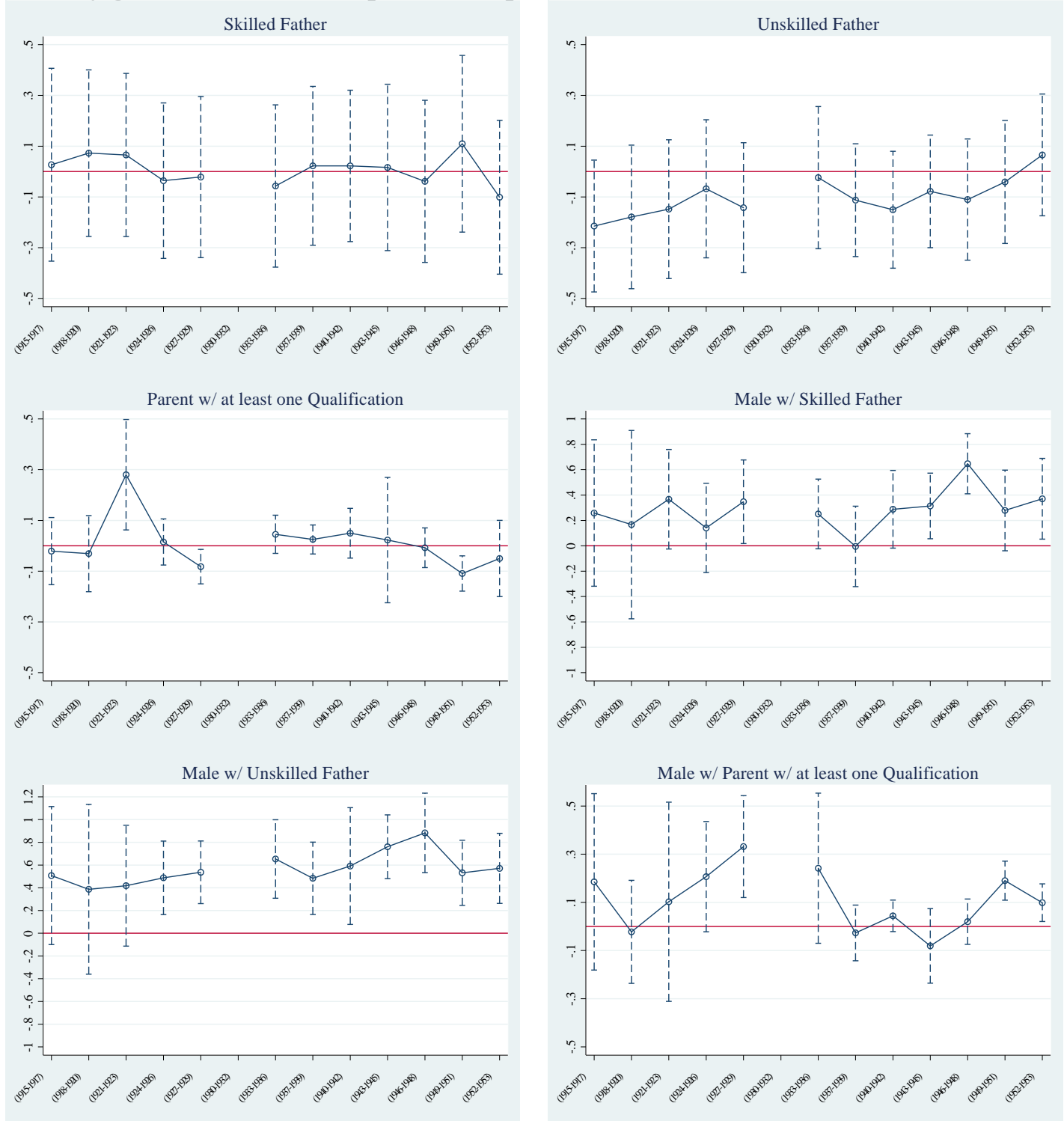

Notes: The figure plots coefficients from linear probability regressions of going to grammar school on 3-year birth cohort indicator variables. The 3-year birth cohort variable (1930-1933) is omitted, so that coefficients are measured relative to this cohort. Year of birth fixed effects, individual characteristics and parental year of birth are included in each regression. The dashed lines present $95 \%$ confidence intervals, with standard errors clustered by year of birth. 


\section{Appendix Table A1. List of variables used in the analysis. All variables taken from or computed from (different waves of) the BHPS}

\begin{tabular}{|c|c|}
\hline Variables & \\
\hline Grammar school & $\begin{array}{l}\text { Dummy variable taking the value of one if respondent } \\
\text { attended grammar school }\end{array}$ \\
\hline $\begin{array}{l}\text { Occupational class of father ( } \mathrm{ref} \text { cat: } \\
\text { professional/manager): }\end{array}$ & Self-reported socio-economic class of father's job \\
\hline Skilled & $\begin{array}{l}\text { Dummy variable if father has non manual or manual skilled } \\
\text { occupation }\end{array}$ \\
\hline Unskilled & $\begin{array}{l}\text { Dummy variable if father has unskilled or partly skilled } \\
\text { occupation }\end{array}$ \\
\hline Noqual & Dummy variable if neither parent has a qualification \\
\hline Gender (Female is ref. cat.) & $\begin{array}{l}\text { Dummy variable taking the value of one if respondent is } \\
\text { male }\end{array}$ \\
\hline $\begin{array}{l}\text { Self reported books at home between } \\
\text { O-10 years of age (ref cat: } \text { no books) }\end{array}$ & Dummy variable if answer is 'quite a few' or a 'lot' \\
\hline Position in family (ref cat: only child) & \\
\hline First child & Dummy variable \\
\hline Second child & Dummy variable \\
\hline Third child & Dummy variable \\
\hline Fourth child & Dummy variable \\
\hline Fifth or later child & Dummy variable \\
\hline District of birth dummies & 32 county dummy variables \\
\hline Area of birth (ref cat: inner city) & Type of area most lived when respondent was young \\
\hline Suburban area & Dummy variable \\
\hline Town & Dummy variable \\
\hline Village & Dummy variable \\
\hline Rural or countryside & Dummy variable \\
\hline Mixed/moved around & Dummy variable \\
\hline Respondent's date of birth & Dummy variables \\
\hline Year of father's birth & Continuous variable (linear trend) \\
\hline Year of mother's birth & Continuous variable (linear trend) \\
\hline Qualifications (ref cat: None) & $\begin{array}{l}\text { Dummy variable if respondent holds School Certificate and } \\
\text { Higher Certificate or at least one A- or O levels }\end{array}$ \\
\hline
\end{tabular}

